\title{
CCL18 wt Allele
}

National Cancer Institute

\section{Source}

National Cancer Institute. CCL18 wt Allele. NCI Thesaurus. Code C49723.

Human CCL18 wild-type allele is located in the vicinity of $17 q 11.2$ and is approximately 7 $\mathrm{kb}$ in length. This allele, which encodes C-C motif chemokine 18 protein, is involved in the chemotactic regulation of naive T cells, CD4+ and CD8+ T cells, and nonactivated lymphocytes involved in inflammatory processes. CCL18 allele may also be involved in B cell migration into lymph node follicles as well as humoral and cell-mediated immunity. 